\title{
Pengaruh Nilai-Nilai Kearifan Lokal Terhadap Pola Pengasuhan Anak Usia Dini (AUD)
}

\author{
Suwardi $^{1}$, Siti Rahmawati ${ }^{2}$ \\ ${ }^{1}$ Program Studi PG PAUD, Fakultas Psikologi dan Pendidikan, Universitas Al Azhar Indonesia, \\ Kompleks Masjid Agung Al Azhar, Jl. Sisingamangaraja, Kebayoran Baru Jakarta Selatan, 12110 \\ ${ }^{2}$ Program Studi Psikologi, Fakultas Psikologi dan Pendidikan, Universitas Al Azhar Indonesia, \\ Kompleks Masjid Agung Al Azhar, Jl. Sisingamangaraja, Kebayoran Batu, Jakarta Selatan 12110
}

Penulis untuk Korespondensi/E-mail: suwardi@uai.ac.id

\begin{abstract}
Abstrak - Saat ini, lemabaga Pendidikan Anak Usia Dini (PAUD) mulai menerima banyak tuntutan, mulai dari tuntutan standar kurikulum nasional yang selalu berubah ubah, tuntutan lingkungan, tuntutan dari orangtua serta tuntutan dari perkembangan ilmu pengetahuan dan teknologi. Sehingga bermunculan faham-faham idealis yang dapat menghilangkan hakikat dan prinsip dasar pendidikan pada anak usia dini. Salah satu fungsi sekolah yaitu, mengajarkan nilai-nilai kebudayaan agar tetap sesuai dengan masyarakat yang semakin maju dan komplek dengan tidak meninggalkan kultur kebudayaan. Sekolah mempunyai peranan besar dalam menjaga eksistensi nilai-nilai luhur tersebut. Metode yang digunakan jenis penelitian deskriptif kuantitatif, yaitu penelitian yang menggunakan statistik dan banyak menggunakan logika hipotetika verifikatif. Pendekatan dimulai dengan berpikir deduktif untuk menurunkan hipotesis, kemudian melakukan pengujian di lapangan, sedangkan hipotesis ditarik berdasarkan data empiris. Untuk membangun nilai-nilai kearifan lokal sejak dini kepada anakanak, dimulai dengan pengenalan dan pembiasanaan perilaku sehari-hari itupun sudah menjadi bagian dari internalisasi nilai-nilai kearifan lokal sebagai upaya melaksanakan pendidikan berbasis keunggulan lokal.
\end{abstract}

Abstract - Currently, Early Childhood Education Institutions (PAUD) are starting to receive many demands, ranging from the demands of ever-changing national curriculum standards, environmental demands, demands from parents and demands from the development of science and technology. So that idealist ideals emerge which can eliminate the nature and basic principles of education in early childhood. One of the functions of the school is to teach cultural values to remain in line with an increasingly advanced and complex society without leaving cultural culture. Schools have a big role in maintaining the existence of these noble values. The method used is descriptive quantitative research, namely research that uses statistics and many use hypothetical verification logic. The approach starts with deductive thinking to derive the hypothesis, then perform testing in the field, while the hypothesis is drawn based on empirical data. To build the values of local wisdom from an early age to children, starting with the introduction and refraction of daily behavior, it has become part of the internalization of the values of local wisdom as an effort to implement education based on local excellence.

Keywords - Early Childhood, Local Wisdom, Parenting Patterns,

\section{PENDAHULUAN}

Saat ini, lembaga pendidikan anak usia dini semakin mendapatkan banyak tuntutan, mulai dari tuntutan standar kurikulum nasional yang selalu berubah ubah, tuntutan lingkungan, tuntutan dari orangtua serta tuntutan dari perkembangan ilmu pengetahuan dan teknologi. Sehingga bermunculan faham-faham idealis yang dapat menghilangkan hakikat dan prinsip dasar pendidikan pada anak usia dini. Banyak permasalahan yang muncul pada diri orangtua, utamanya adalah orangtua berekonomi menegah yang berdomisili di pedesaan, mereka berpendapat bahwa anak akan lebih maju jika mereka disekolahkan di kota, anak akan lebih pintar jika sejak dini mereka sudah mengenal pendidikan di daerah perkotaan, sehingga banyak fenomena yang terjadi saat ini bahwa orangtua berhijrah untuk 
menyekolahkan buah hatinya di tempat yang dianggap lebih baik.

Permasalahan dari potret kasus di atas seharusnya bisa dijadikan sebagai tolak ukur lembaga pendidikan sebagai tantangan masa depan, inovasi kurikulum di tingkat satuan pendidikan adalah hal yang mutlak harus dilakukan jika lembaga pendidikan tersebut ingin survive. Secara mendasar pendidikan di lembaga formal berfungsi sebagai wahana sosialisasi dan wadah yang membantu anakanak dalam mempelajari cara menyesuaikan diri dengan lingkungan. Sekolah berfungsi mentransmisi dan mentransformasi kebudayaan, mengajarkan nilai-nilai kebudayaan dari generasi tua ke generasi muda. Sekolah berfungsi mentransformasi budaya, artinya untuk mengubah bentuk kebudayaan agar tetap sesuai dengan masyarakat yang semakin maju dan komplek dengan tidak meninggalkan kultur kebudayaan kita. Oleh karena itu nilai-nilai luhur yang telah diwariskan oleh generasi tua ke generasi muda tidak boleh ditinggalkan, maka sekolah mempunyai peranan besar dalam menjaga eksistensi nilai nilai luhur tersebut. Sebab dalam kurun waktu yang bersamaan sekolah dituntut untuk menjawab tantangan kemajuan teknologi serta komunikasi global yang semakin canggih dan kompleks.

Nilai-nilai luhur itu biasa disebut dengan istilah kearifan lokal (local wisdom). Kearifan lokal atau sering disebut local wisdom dapat dipahami sebagai usaha manusia dengan menggunakan akal budinya (kognisi) untuk bertindak dan bersikap terhadap sesuatu, objek, atau peristiwa yang terjadi dalam ruang tertentu, suatu hal yang menjadi nilai lebih dalam konteks kearifan lokal adalah bahwa nilai nilai etika dan estetika luhur nya bisa menjadi sebuah langkah awal untuk mewujudkan pendidikan berbasis keunggulan lokal yaitu sebuah konsep pendidikan yang mencakup segala sesuatu yang menjadi ciri khas kedaerahan baik yang meliputi ekonomi, budaya, teknologi, komunikasi, ekologi dan lain sebagainya.

Anak usia dini adalah anak pada rentangan usia 4 - 6 tahun yang mengikuti pendidikan di lembaga AUD. Pendidikan di lembaga AUD merupakan pendidikan sebagai wahana untuk menyiapkan anak dari segi sikap, pengetahuan, dan keterampilan guna memasuki sekolah dasar. Berkaitan dengan perannya, guru atau pendamping anak usia dini, harus mampu bersikap lebih terbuka dalam memberi informasi dan menanggapi pertanyaan-pertanyaan anak yang serba transparan.
Tujuan penelitian ini adalah pihak sekolah (guruguru) mempunyai peranan besar dalam menjaga eksistensi nilai-nilai luhur tersebut, maka sangat penting untuk memperkenalkan nilai-nilai kearifan lokal sejak dini kepada anak-anak. Dimulai dengan pengenalan dan pembiasaan perilaku sehari-hari itupun sudah menjadi bagian dari internalisasi nilainilai kearifan lokal sebagai upaya melaksanakan pendidikan berbasis keunggulan lokal.

\section{Kearifan Lokal}

Bila dilihat dari kamus Inggris-Indonesia, terdiri dari dua kata, yaitu kearifan (wisdom) dan lokal (local). Local yang berarti setempat, sementara wisdom sama dengan kebijaksanaan. Dengan demikian maka dapat dipahami, bahwa pengertian kearifan lokal merupakan nilai-nilai, pandangan-padangan setempat atau (lokal) yang bersifat bijaksana, penuh kearifan, bernilai baik yang tertanam dan diikuti oleh anggota masyarakatnya. Kearifan lokal adalah produk (ide, praktek, dan hasil karya) kebudayaan para pemangkunya mengenai lingkungan dan manusia yang berbasis ke-Tuhanan, kemanusiaan, dan lingkungan yang menyatu sedemikian rupa sehingga menjamin harmoni antara manusia dan alam sekitarnya [1].

Kearifan lokal pada anak usia dini adalah nilai-nilai sikap yang mendasari perilaku anak, yang dilandasi oleh nilai-nilai luhur budaya kita. Nilai-nilai luhur budaya kita dapat dilestarikan dengan jalan mewariskan dari generasi tua ke generasi muda melalui pendidikan, baik itu pendidikan formal, informal, maupun nonformal. Dengan demikian dapat dikatakan bahwa kebudayaan dan pendidikan mempunyai hubungan timbal balik. Sebaliknya bentuk, ciri-ciri dan pelaksanaan pendidikan itu ditentukan oleh kebudayaan masyarakat dimana proses pendidikan itu berlangsung. Kearifan lokal diperlukan untuk terciptanya ketertiban, kedamaian, keadilan, mencegah konflik, kesopanan, kesejahteraan, ilmu pengetahuan, pendidikan, pengembangan sistem nilai, pengembangan kelembagaan, dan perubahan tingkah laku. dan terdapat norma sosial yang menjunjung perdamaian, kebersamaan dan gotong royong. Kearifan lokal apabila diterjemahkan secara bebas dapat diartikan nilai-nilai budaya yang baik yang ada di dalam suatu masyarakat. Hal ini berarti, untuk mengetahui suatu kearifan lokal di suatu wilayah maka kita harus bisa memahami nilai-nilai budaya yang baik yang ada di dalam wilayah tersebut. Sebenarnya nilai-nilai kearifan lokal ini sudah diajarkan secara turun temurun oleh orangtua kepada anak-anaknya. Budaya gotong royong, saling menghormati dan 
tepa salira merupakan contoh kecil dari kearifan lokal. Budaya lokal adalah budaya yang dimiliki oleh masyarakat yang menempati lokalitas atau daerah tertentu yang berbeda dari budaya yang dimiliki oleh masyarakat yang berada di tempat yang lain. Permendagri Nomor 39 Tahun 2007 pasal 1 mendefinisikan budaya daerah sebagai suatu sistem nilai yang dianut oleh komunitas/ kelompok masyarakat tertentu di daerah, yang diyakini akan dapat memenuhi harapan-harapan warga masyarakatnya dan di dalamnya terdapat nilai-nilai, sikap tatacara masyarakat yang diyakini dapat memenuhi kehidupan warga masyarakatnya [2].

Adapun fungsi kearifan lokal yaitu (1) Untuk konservasi dan pelestarian sumber daya alam (2) Untuk pengembangan sumber daya manusia (3) Untuk pengembangan kebudayaan dan ilmu pengetahuan (4) Sebagai petuah, kepercayaan, sastra dan pantangan (5) Bermakna sosial yang terlihat dalam upacara suatu komunitas atau kerabat (6) Bermakna etika dan moral; serta (7) Bermakna politik. [3]

Kearifan lokal membawa pesan kepada masyarakat dalam proses penyelesaian masalah di lingkungan sehingga semangat mengangkat kearifan lokal sebagai salah satu solusi dalam pemecahan permasalahaan dan memberikan penekanan bahwa kearifan lokal adalah produk budaya yang dapat menyatu tatanan kehidupan agar lebih serasi dan adanya penekanan akan penting partisipasi masyarakat dalam penciptaan kearifan kehidupan patut dihargai dan perlu digalakan pengalianpengalian kearifan lokal yang banyak tersebar di bumi nusantara ini.

\section{Pendidikan Berbasis Kearifan Lokal}

Pendidikan berbasis kearifan lokal ialah sesuai dengan yang telah termaktub dalam undang- undang nasional yaitu Undang - undang (UU) No 20 Tahun 2003 Tentang Sistem Pendidikan Nasional pada Pasal 3, menyebutkan bahwa pendidikan nasional berfungsi mengembangkan kemampuan dan membentuk karakter serta peradaban bangsa yang bermartabat dalam rangka mencerdaskan kehidupan bangsa. Pendidikan nasional bertujuan untuk berkembangnya potensi peserta didik agar menjadi manusia yang beriman dan bertakwa kepada Tuhan Yang Maha Esa, berakhlak mulia, sehat, berilmu, cakap, kreatif, mandiri, dan menjadi warga negara yang demokratis serta bertanggung jawab. Manfaat pendidikan yang berbasis kepada kearifan lokal antara lain ialah (1) Melahirkan generasi-generasi yang kompeten dan bermartabat (2) Merefleksikan nilai-nilai budaya (3) Berperan serta dalam membentuk karakter bangsa (4) Ikut berkontribusi demi terciptanya identitas bangsa, (5) Ikut andil dalam melestarikan budaya bangsa.

\section{Pola Pengasuhan Anak Usia Dini}

Pola asuh dalam keluarga pada anak ada empat macam, yaitu : Otoriter, Permitif, Demokratis, dan Situasioanal : 1. Otoriter adalah pola asuh yang memaksa, semua perintah orangtua harus dipatuhi oleh anak-anaknya dan hukuman merupakan tindakan dalam proses pengasuhan ini, sehingga anak melaksanakan perintah atau tugas dari orangtua karena takut memperoleh hukuman dari orangtuanya. Dampak negatif yang terjadi pada anak dari metode Otoriter adalah anak lebih suka menyendiri, penakut, agresif dan nakal di lingkungan luar karena anak merasa jika diluar rumah tidak ada aturan yang memaksa. 2. Permitif adalah pola asuh yang dimanjakan, semua kehendak anak dibiarkan saja dan dituruti semua keinginannya bahkan orangtua tidak pernah memberikan teguran terhadap anak. Dampak negatif yang terjadi pada anak adalah anak menjadi sangat manja, keras kepala dan sering mogok jika permintaannya tidak dituruti. 3. Demokratis adalah pola asuh dengan komunikasi yang stabil, artinya anak diberi kebabasan untuk berpendapat dan orangtua membantu tumbuh kembang anak serta mendukung bakat minat yang dimiliki oleh anak. Tidak ada dampak negatif dalam pola Demokratis dikarenakan anak akan menjadi tumbuh dewasa dengan cerdas, kreatif serta patuh dengan perintah secara wajar, anak tumbuh percaya diri, dapat menyesuaikan dirinya dengan lingkungan, dan anak dapat bertanggung jawab. Pola asuh Demokratis sangat cocok diterapkan oleh orangtua terhadap anaknya. 4. Situasioanal adalah pola asuh yang sesuai situasi. Pola asuh Situasional termasuk campuran dari 3 macam pola asuh diatas. Kadang orangtua bersikap otoriter, tapi kadang juga permisif namun kadang juga berupaya menerapkan demokrasi di rumah.

\section{METODE}

Masalah yang diteliti adalah masalah yang baru, maka penulis menggunakan jenis penelitian deskriptif kuantitatif, yaitu penelitian yang menggunakan statistik dan banyak menggunakan logika hipotetika verifikatif. Pendekatan dimulai dengan berpikir deduktif untuk menurunkan hipotesis, kemudian melakukan pengujian di lapangan. Kesimpulan atau hipotesis ditarik berdasarkan data empiris. 
Penelitian deskriptif adalah "penelitian yang berusaha mendeskreptifkan suatu gejala, peristiwa, kejadian yang terjadi pada masa seksarang. Dengan kata lain, pengertian deskreptif mengambil masalah atau memusatkan perhatian kepada masalahmasalah aktual sebagaimana adanya pada saat penelitian dilaksanakan.” [4]

Ciri utama dari metode deskriptif kuantitatif adalah memberikan gambaran dan tafsiran terhadap gejalagejala yang terjadi saat ini dengan menggunakan angka-angka dari studi kasus yang diteliti. Menurut [5] metode penelitian pendidikan dapat diartikan sebagai "cara ilmiah untuk mendapatkan data yang valid dengan tujuan dapat ditemukan, dikembangkan, dan dibuktikan, suatu pengetahuan tertentu sehingga pada gilirannya dapat digunakan untuk memahami, memecahkan, dan mengantisipasi masalah dalam bidang pendidikan. Metode penelitian yang digunakan dalam penelitian ini adalah metode survei. Metode penelitian yang digunakan penulis adalah penelitian lapangan terhadap studi kasus yang dilakukan dengan desain deskriptif dan kausal, yang memecahkan suatu kasus yaitu kasus mengenai hubungan nilai-nilai kearifan lokal (variabel X) terhadap pola pengasuhan anak usia dini, dimana $\mathrm{X}$ merupakan variabel bebas serta Y merupakan variabel terikat

\section{Subjek Penelitian}

Sampel dalam penelitian ini adalah sebanyak 100 orang di lembaga Anak Usia Dini (AUD) yang diambil secara sampling acak sederhana berdasarkan populasi terjangkau sebesar $65 \%$. Hal ini sesuai dengan pendapat [6] yaitu, sampling acak adalah metode pengambilan sampel dari suatu populasi atau semesta sedemikian rupa, sehingga semua sampel yang terpilih besarnya tetap dan memiliki kemungkinan yang sama untuk terpilih. Kemudian untuk menentukan besar kecilnya sampel tidak ada ketentuan mutlak. Untuk menentukan validitas dan reliabilitas instrumen maka dibutuhkan subjek sampel paling sedikit 50 orang [7].

\section{Teknik Pengumpulan Data}

\section{Pengumpulan Data Primer}

Variabel-variabel yang diteliti terdapat pada unit analisis yang bersangkutan dalam sampel penelitian. Data yang dikumpulkan dari setiap variabel ditentukan oleh definisi operasional variabel yang bersangkutan. Definisi operasional itu menunjuk pada dua hal yang penting dalam hubungannya dengan pengumpulan data, yaitu indikator empiris dan pengukuran. Untuk mendapatkan data primer, digunakan instrumen pengumpulan data berupa kuesioner. Kuesioner tersebut berisi beberapa pertanyaan mengenai indikator-indikator pengaruh nilai-nilai kearifan lokal terhadap pola pengasuhan anak usia dini. Jawaban menggunakan skala Likert 5 tingkatan jawaban, yaitu 5 untuk jawaban Selalu, 4 untuk jawaban Sering, 3 untuk jawaban Kadang, 2 untuk jawaban Jarang dan 1 untuk jawaban Tidak Pernah. Pengumpulan data primer dilakukan melalui kegiatan penelitian lapangan (field research).

\section{Pengumpulan Data Sekunder}

Pengumpulan data sekunder dilakukan melalui kegiatan penelitian kepustakaan (library research) dengan cara mempelajari sumber bacaan atau dokumen-dokumen penting. Teori-teori tersebut diambil dengan cara mengutip, baik secara langsung maupun tidak langsung.

\section{Instrumen Penelitian}

\section{Pola Pengasuhan Anak Usia Dini Definisi Konseptual}

Pola pengasuhan anak usia dini adalah cara orangtua dalam mendidik anak. cara yang dilakukan orangtua dalam mendidik anaknya sebagai bentuk tanggung jawabnya kepada anak. Pola asuh orangtua adalah bagaimana cara mendidik orangtua terhadap anak, baik secara langsung maupun tidak langsung.

\section{Definisi Operasional}

Definisi operasional yaitu pola asuh dalam keluarga pada anak ada empat macam, yaitu: Otoriter, Permisif, Demokratis, dan Situasional

\section{Instrumen Nilai-nilai Kearifan Lokal}

\section{Definisi Konseptual}

Nilai-nilai kearifan lokal adalah sikap setia dan perilaku patuh dalam menjaga dan memelihara organisasi agar tetap berjalan secara berkesinambungan dengan indikator (1) berjanji setia, menjaga kesetiaan, memelihara organisasi, dan bangga pada sekolah, (2) berperilaku patuh, (3) sikap setia (4) adanya keterbukaan,

\section{Definisi Operasional}

Nilai-nilai kearifan lokal adalah ungkapan sikap dan aktivitas anak usia dini. Sikap dan aktivitas anak usia dini dapat dilihat dengan penyebaran kuisioner. Kuisioner yang digunakan berisi 30 butir pertanyaan yang berbentuk penilaian menggunakan skala Likert. Skor nilai-nilai kearifan lokal diperoleh dari jumlah skor 30 butir pernyataan dengan rentang skor terletak antara 30 sampai 150 . 


\section{Teknik Analisa Data}

\section{Analisis Deskriptif dan Inferensial}

Dalam analisis deskriptif akan dilakukan teknik penyajian data dalam bentuk tabel distribusi frekuensi, grafik poligon dan histogram untuk masing-masing variabel penelitian. Selain itu juga masing-masing kelompok data akan diolah dan dianalisis ukuran pemusatan dan letak seperti mean, modus, dan median serta ukuran simpangan seperti jangkauan, variansi, simpangan baku, kemencengan dan kurtosis. Proses pengolahan untuk menguji analisis deskriptif tersebut dilakukan dengan menggunakan program SPSS 22.0.

Data yang diperoleh dari hasil penelitian dianalisis dengan menggunakan analisis statistik deskriptif dan analisis statistik regresi. Analisis statistik deskriptif dilakukan dengan mendeskripsikan semua data dari semua variabel dalam bentuk; distribusi frekuensi, histogram, modus, median, harga rata-rata serta simpangan baku (standar deviasi). Sedangkan analisis statistik regresi dilakukan untuk menguji pengaruh hipotesis yang telah dirumuskan. Sebelumnya terlebih dahulu dilakukan pengujian persyaratan analisis yaitu uji normalitas dan uji homogenitas.

\section{Uji Persyaratan Analisis Data}

Uji persyaratan analisis data bertujuan untuk mengetahui apakah data yang telah dikumpulkan layak untuk dianalisis lebih lanjut menggunakan alat-alat statistik. Pengujian yang dilakukan adalah pengujian normalitas data, pengujian linieritas, dan pengujian multikolinieritas yang secara keseluruhan dibantu oleh program komputer SPSS 22.0. Adapun kriteria pengujian untuk normalitas adalah: jika nilai sig. > 0,05; maka data berdistribusi normal dan jika nilai sig. $<0,05$; maka data tidak beridistribusi normal.

Sementara itu kriteria pengujian linieritas adalah jika $F_{\text {hitung }}>F_{\text {tabel }}$ atau nilai sig. $<0,05$; maka persamaan regresi linier. Jika $F_{\text {hitung }}<F_{\text {tabel }}$ atau nilai sig. $>0,05$; maka persamaan regresinya tidak linier. Uji multikolonieritas dapat dilihat dari besarnya VIF (Varians Inflation Factor) dan tolerance. Pedoman suatu model regresi yang bebas multikolinieritas adalah yang mempunyai nilai VIF di sekitar angka 1 dan memiliki toleransi mendekati 1 .

\section{HASIL DAN PEMBAHASAN}

Berlandaskan pada teori-teori yang mendukung selanjutnya dibuat sintesis berupa indikator dari variabel nilai-nilai kearifan lokal dan pola pengasuhan anak usia dini. Variabel nilai-nilai kearifan lokal dan pola pengasuhan anak usia dini memiliki lima kategori jawaban, yaitu (1) Selalu, (2) Sering, (3) Kadang-kadang, (4) Jarang, dan (5) Tidak Pernah. Kategori pernyataan positif diberi bobot 5 (lima) sampai dengan 1 (satu), sedangkan kategori pernyataan negatif diberi bobot nilai sebaliknya, yaitu 1 (satu) sampai dengan 5 (lima). Uji validitas instrument nilai-nilai kearifan lokal dilakukan dengan bantuan SPSS 22.0. Berdasarkan hasil perhitungan validitas instrumen kearifan lokal diketahui dari 30 butir pernyataan terdapat 1 butir yang tidak valid (drop), yaitu butir nomor 9. Dengan demikian jumlah butir yang valid dan digunakan sebagai alat pengambil data penelitian sebanyak 29 butir.

Perhitungan koefisien reliabilitas instrumen nilainilai kearifan lokal dilakukan setelah butir yang tidak valid (drop) tidak digunakan dalam penelitian sehingga tidak diperhitungkan dalam perhitungan ini. Dengan demikian perhitungan reliabilitas instrumen variabel kearifan lokal sebanyak 29 butir diperoleh hasil 0,870. Perhitungan dilakukan dengan menggunakan bantuan program SPSS 22.0.

Untuk mengetahui validitas butir instrument pola pengasuhan anak usia dini dengan melihat besaran $\mathrm{r}_{\mathrm{xy}}$ yang diperoleh dibandingkan dengan harga kritis $\mathrm{r}$ Product Moment pada $\mathrm{n}=30$. Jika $\mathrm{r}_{\text {hitung }} \geq \mathrm{r}$ tabel, maka butir instrumen tersebut valid dan selanjutnya akan digunakan untuk menjaring data. Sebaliknya, jika $\mathrm{r}_{\text {hitung }}<\mathrm{r}$ tabel, maka butir tersebut tidak valid (drop) dan selanjutnya tidak digunakan untuk menjaring data penelitian. Dalam tabel harga kritis $\mathrm{r}_{\text {tabel }}$ Product Moment diketahui 0,361 untuk $\mathrm{n}=30$ dengan $\alpha=0,05$. Uji reliabilitas instrumen pola pengasuhan anak usia dini dilakukan dengan bantuan SPSS 22.0 Berdasarkan hasil perhitungan validitas instrumen pola pengasuhan anak diketahui dari 30 butir pertanyaan, 1 butir yang tidak valid (drop), yaitu butir nomor 20. Dengan demikian jumlah butir yang valid dan digunakan sebagai alat pengambil data penelitian sebanyak 29 butir.

Perhitungan koefisien reliabilitas instrumen pola pengasuhan anak usia dini dilakukan setelah butir yang tidak valid (drop) tidak digunakan dalam penelitian sehingga tidak diperhitungkan dalam perhitungan ini. Dengan demikian perhitungan reliabilitas instrumen variabel sebanyak 29 butir diperoleh hasil 0,950. Perhitungan dilakukan dengan menggunakan bantuan program SPSS 22.0. 
Pola pengasuhan anak usia dini nilai rata-rata skor sebesar 333,3; angka tersebut berada ke dalam kategori sedang. Hasil pengujian hipotesis diketahui nilai $t_{\text {hitung }}(10,719)>t_{\text {tabel }}(1,661)$ dengan signifikansi $0,000<0,1$ maka $\mathrm{H}_{\mathrm{o}}$ ditolak atau $\mathrm{H}_{\mathrm{a}}$ diterima. Ini artinya ada pengaruh yang signifikan pola pengasuhan anak terhadap nilai-nilai kearifan local di Lembaga Pendidikan Anak Usia Dini Jakarta Selatan. Besaran pengaruh dari variabel pola asuh orangtua terhadap pengasuhan anak sebesar $54 \%$, sedangkan sisanya $46 \%$ dipengaruhi oleh faktor lain diluar variabel pola pengasuhan anak.

\section{KESIMPULAN}

Pelaksanaan nilai-nilai kearifan lokal terhadap pola pengasuhan anak usia dini terdapat dampak yang positif, sehingga dapat disimpulkan: Masyarakat dalam hal ini lembaga PAUD lebih intensif dalam kegiatan sosialiasasi teknis pelaksanaannya, sehingga diperlukan pelatihan kepada guru-guru agar lebih tercerahkan dalam membangun nilai-nilai kearifan lokal terhadap pola pengasuhan anak usia dini dengan memperluas dan memperkuat kerjasama lembaga PAUD bersama orangtua serta lingkungan sekitar agar lebih bersinergi.

\section{REFERENSI}

[1] I. Hamad, Komunikasi dan Perilaku Manusia, Jakarta: Rajawali Pers, 2013.

[2] Dirjen Kesbangpol Depdagri, Permendagri Nomor 39 Tahun 2007, Jakarta : Kementrian Dalam Negeri, 2017.

[3] Sartini, "Wacana Pragmatis Berbagai Agama Baru Di Jepang," Jurnal Filsafat, vol. 16, no. 2, 2006.

[4] N. Sudjana, Penelitian dan Penilaian Pendidikan, Bandung: Sinar Baru Algesindo, 20014.

[5] Sugiyono, Metode Penelitian Kuantitatif Kualitatif dan R\&D, Bandung: Alfabeta, 2008.

[6] Kerlinger, Foundations of Behavioral Research, San Diego: Harcourt College Publishers, 2000.

[7] F. G. Winarno, Kimia Pangan dan Gizi, Jakarta: Gramedia Pustaka, 1997. 